$\begin{gathered}\text { Revista do Departamento de Geografia } \\ \text { Universidade de São Paulo } \\ \text { www.revistas.usp.br/rdg }\end{gathered}$
V.32 (2016)
ISSN 2236-2878

\title{
Os Agentes Produtores do Espaço Urbano nas Recentes Tendências do Mercado Imobiliário Costarriquenho
}

\author{
Agents Involved in The Production of City Space in the Recent \\ Costa Rican Real Estate Market Trends
}

\author{
Sabrine Acosta Schnell \\ Universidad de Costa Rica \\ sabrigeografia@hotmail.com
}

Resumo: Na entrada do século XXI na Costa Rica, no quadro da urbanização neoliberal, o mercado está impondo uma nova forma de morar: a verticalização residencial. Neste contexto, este artigo apresenta uma análise sobre a relação entre os diferentes agentes imobiliários e o papel do Estado. Este artigo tem como objetivo utilizar um marco referencial teórico pouco abordado nos estudos de geografia urbana costarriquenha. Utiliza-se o caso de estudo dos arredores do Parque Metropolitano La Sabana, em San José, a cidade capital, para exemplificar a rede complexa entre os diversos atores produtores do solo urbano.

Palavras-chave: Verticalização Residencial, Mercado Imobiliário, Planificação Urbana, Uso do Solo.

\begin{abstract}
Starting the XXI century in Costa Rica, in the context of neoliberal urbanization, market is imposing a new way of living: vertical housing. In this context, this article presents an analysis of the relationship between the different real estate agents and the government's role. This article aims to use a theoretical framework rarely addressed in studies of Costa Rican urban geography. It uses the case study of the surroundings of the La Sabana Metropolitan Park, at San José, the capital city, in order to exemplify the complex network between the various agents involved in the production of urban space.
\end{abstract}

Keywords: Vertical Housing, Real Estate Market, Urban Space, Urban Management. 


\section{INTRODUÇÃO}

Durante o século XX, o processo de urbanização na Costa Rica passou por diversas etapas respondendo a diferentes mudanças no âmbito político, social e econômico. As que foram terras cultiváveis para a produção cafeeira desde o século XIX, começaram a ser divididas em loteamentos menores para serem vendidas no contexto de uma rápida mudança no uso do solo. Na Costa Rica não ocorreu um marcado e forte processo de industrialização como parte do programa "substituição de importações", tal e como aconteceu em outros países da América Latina. A cidade de San José começou a presenciar uma expansão urbana horizontal para albergar a crescente população que se dedicava principalmente ao setor serviços.

A verticalização residencial não foi uma tendência no país altamente sísmico. Desde 1950, alguns edifícios residenciais foram associados aos segmentos mais baixos já que, na maioria, foram projetos de habitação de interesse social. Atualmente, na entrada do século XXI, o mercado residencial impulsionou uma forte verticalização das residências como símbolo de luxo (SCHNELL, 2014). Neste contexto se apresentarão as relações entre os diferentes atores produtores do espaço urbano na Costa Rica.

\section{Os atores produtores do espaço urbano na Costa Rica}

Atualmente na Costa Rica, existe um amplo mercado imobiliário com um grande número de participantes. Não existe somente um fluxo de relações entre eles, mas desenvolve-se um complexo jogo de forças em diversas escalas (SCHNELL, 2014). Funciona como uma rede de participação com diversos agentes que influem na produção do espaço entre os quais se destacam os proprietários fundiários urbanos, proprietários imobiliários urbanos, produtores de materiais de construção, incorporadores, ${ }^{1}$ empresas de consultoria ambiental, ${ }^{2}$ construtoras, investidores independentes, investidores associados, entidades bancárias (públicas e privadas) e as entidades financeiras não bancárias, instituições governamentais (encarregadas de outorgar os licenciamentos), compradores de terrenos e de moradias (demanda final ou usuário) e $\mathrm{O}$ Estado.

Cada um realiza uma combinação de funções de financiamento, promoção, estudo técnico, construção, comercialização, venda e administração. Por exemplo, está o comprador, que é indispensável para que haja mercado. O incorporador é a empresa encarregada desde a compra do terreno até a venda para o consumidor final. Segundo Souza (1994), o incorporador é quem desmembra o terreno em "frações ideais" e, portanto, é quem cria o solo e está encarregado de diversas subcontratações que incluem arquitetos e engenheiros para o projeto; a empresa encarregada dos licenciamentos ambientais (a que também se encarrega de diversas subcontratações para realizar os estudos técnicos); os profissionais a cargo da campanha de venda e os advogados necessários para atender os processos legais. $\mathrm{O}$ incorporador é quem assume os riscos e o maior custo no processo de produção do edifício, mas também obtém o maior lucro (SCHNELL, 2014). Existem projetos onde o incorporador decidiu mudar de construtora para a realização das seguintes etapas do projeto.

Essas relações podem parecer complexas já que um agente pode assumir o papel de incorporador, construtor e/ou vendedor dependendo do tipo de empreendimento. Na Costa Rica existe o caso de construtoras que têm incursionado na área dos incorporadores. Construtoras como, por exemplo, a EDIFICAR, que nos inícios do ano 2013 começou a realizar funções de financiar, construir e vender um mesmo projeto. Grupo Inmobiliario del Parque tem financiamento estrangeiro dos Estados Unidos e o modelo de subcontratação consiste em que a mesma empresa ofereça o desenho, a venda e a auditoria. A construção está a cargo de construtoras conceituadas no país como, por exemplo, EDIFICAR, PROICON, Van der Latt, entre outras. Em síntese, as empresas ampliam seu objeto e diversificam suas atividades para outros setores da economia relacionados à verticalização residencial (SCHNELL, 2014).

Entrado o século XXI, os bairros de alto padrão, localizados a poucos quilômetros da capital, começaram a viver as incipientes tendências na mudança no uso do solo (SCHNELL, 2014; ACOSTA, 2016). Atualmente, nestas ruas que se caracterizavam por ser muito tranquilas e de pouco trânsito, diversas propriedades estão sendo alugadas e ocupadas por comércio, escritórios, academias, bancos ou consultórios médicos. Outras são demolidas para abrir espaço para o desenvolvimento de torres (Figura 1). Outros especuladores se negam a vender seus terrenos para poder cobrar mais conforme os anos avançam (Figura 2).

\footnotetext{
${ }^{1}$ Os incorporadores são conhecidos na Costa Rica como desarrolladores.

${ }^{2}$ Subcontratadas pelos incorporadores. 


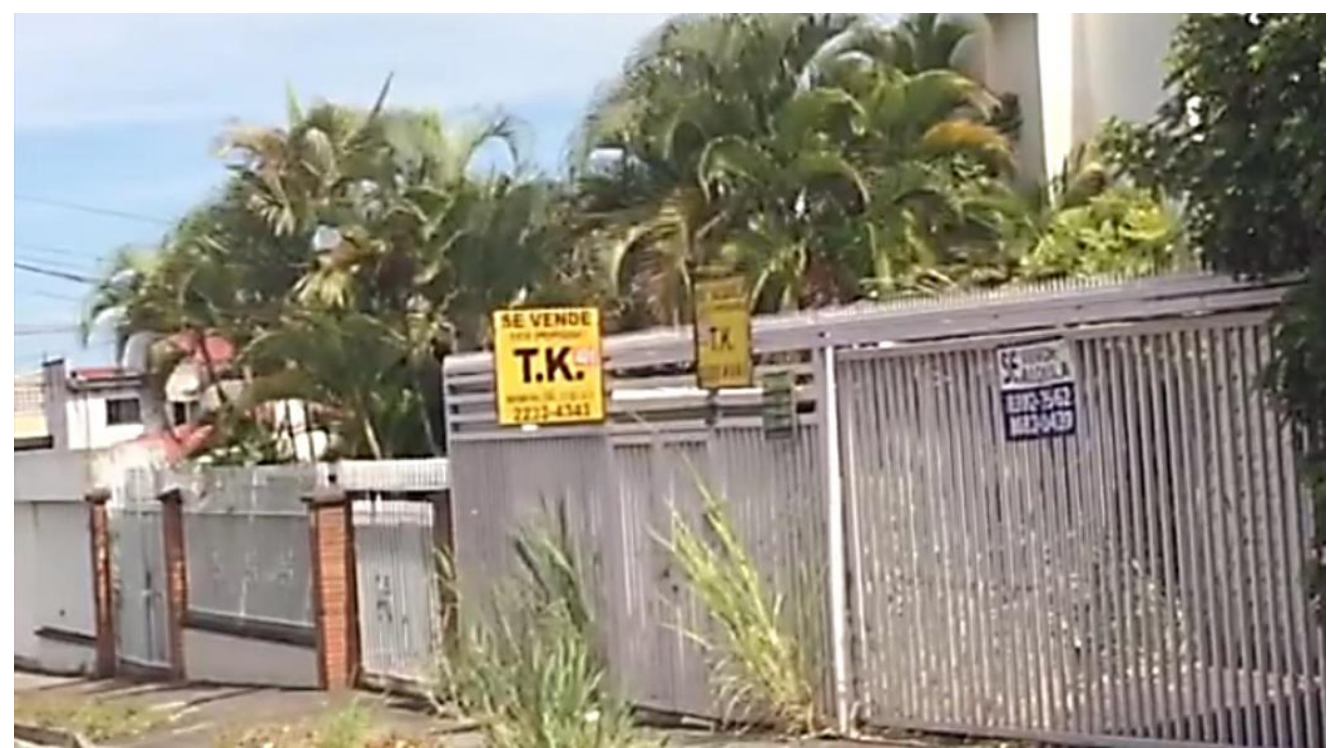

Figura 1: Casas à venda para dar espaço aos novos empreendimentos verticais no bairro de alto padrão, Rohrmoser, março 2016. Fonte: Acervo do Autor, Março 2016.

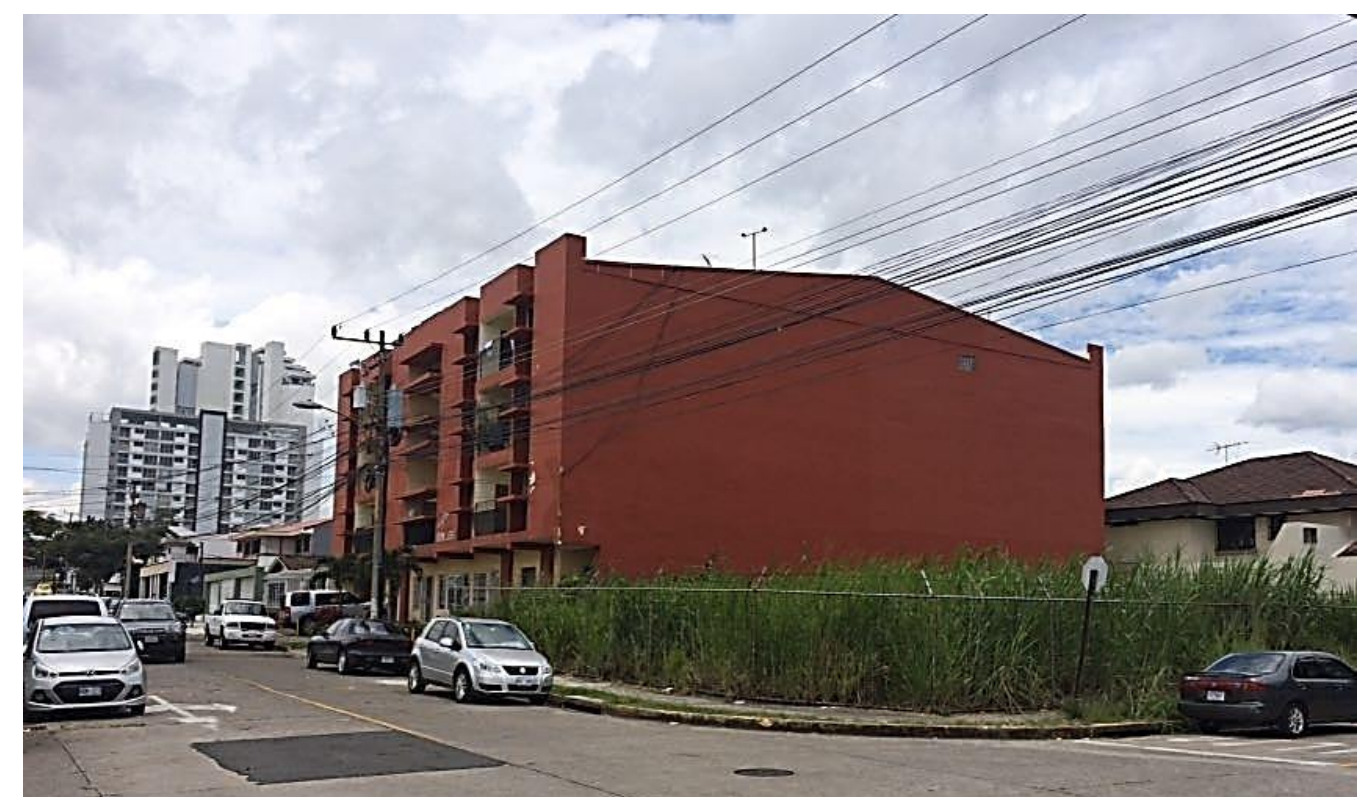

Figura 2: Terreno no bairro Rohrmoser, um dos distritos de alto padrão mais apetecidos pelos empreendedores de projetos verticais. Observam-se outros projetos já concluídos no mesmo bairro. Fonte: Acervo do Autor, Julho 2016.

Novos empreendimentos estão "pipocando" onde antes havia casas de luxo ou terrenos que por muitos anos permaneceram vazios (muitos associados a antigos cafezais em séculos passados) e que atualmente estão dando lugar aos novos projetos verticais de alto padrão (SCHNELL, 2014, ACOSTA 2016). Muitos especuladores desses bairros de alto poder aquisitivo estão analisando esta nova tendência do mercado imobiliário e têm decidido esperar para vender suas propriedades (Figura 2).

Outras terras, não necessariamente associadas ao café, também estão começando a participar no mercado dos especuladores, antecipando as novas tendências de verticalização de moradias de luxo e valorizando novos bairros da cidade. Por exemplo, os bairros de Escazú (ao oeste da capital) estão valorizando rapidamente suas terras em lugares que previamente não estavam associados aos altos padrões (SCHNELL, 2014, ACOSTA, 2016). Inclusive muitas são zonas de alto risco para a construção devido a sua topografia pronunciada e próxima a cursos d'água. No entanto, neste caso, os especuladores tiram vantagem da natureza circundante e começam a vender um estilo de vida "saudável" próximo à cidade. 


\section{O papel do Estado}

Continuando com a análise dos atores participantes na produção do espaço urbano na Costa Rica, podemos analisar o papel do Estado através de diferentes pontos de vista (SCHNELL, 2014). Em primeiro lugar podemos visualizar como o poder público atua na urbanização capitalista de duas formas: como um regulador do processo de urbanização, atenuando os efeitos dos limites capitalistas da urbanização através do zoneamento sem esquecer seu caráter interventor contraditório sobre a socialização das forças produtivas, regulando a concorrência e o preço da terra (PEREIRA, 1992), refletindo uma sociedade de classes. Contudo, através da planificação e da coordenação estatal da ocupação e da utilização do solo urbano, o Estado regula a concorrência entre os diferentes agentes que ocupam o espaço urbano (SCHNELL, 2014).

Dentro do contexto do Estado como ente regulador, se destaca nas palavras de Pereira $(1992$, p. 50) que "[...] o interesse da classe burguesa, na manutenção de sua dominação, se traduz e se realiza na forma de medidas concretas pelas instituições estatais". Esse "interesse" tem existido desde o contato com os espanhóis no período colonial, durante o período republicano e até na atualidade com os atuais segmentos de maior poder aquisitivo. Este é o legado do patrimonialismo, explicado por Maricato (2006), o que se caracteriza por ter uma estreita relação com a propriedade da terra e a concentração do poder político, social e econômico.

Não se pode esquecer o papel contraditório do Estado na gestão do espaço urbano, já que: “[...] a necessidade de desenvolver a socialização das forças produtivas materiais e humanas responde à necessidade oposta, que o capitalismo tem, de subordinar o crescimento econômico unicamente à valorização do capital" (LOJKINE, 1997, p. 193). Nesse cenário, a política urbana aumenta a contradição entre meios de reprodução do capital e meios de reprodução da força de trabalho, tornando-se um instrumento de seleção e de dissociação sistemática dos diferentes tipos de equipamento urbano, de acordo com seu grau de rentabilidade e de utilidade imediata para o capital (LOJKINE, 1997).

Esse papel contraditório do Estado se observa quando a:

A planificação estatal aparece subordinada não à lógica de controle racional, pela sociedade, de seu desenvolvimento coletivo, mas sim à lógica de acumulação do capital privado, a planificação assim como o conjunto da política estatal age menos como instrumento de regulação do que como revelador de uma sociedade retalhada pelo conflito de classes antagônicas (LOJKINE, 1997, p. 343).

Dessa maneira se entende como o Estado, ao distribuir espacialmente os equipamentos urbanos para os diferentes segmentos urbanos, reflete as lutas de classe geradas pela segregação social dos valores de uso urbano. É uma distribuição segregativa (PEREIRA, 1992).

O Estado também participa do processo de liberação do solo, da configuração territorial da urbanização e consequentemente da distribuição dos diferentes segmentos sociais nos bairros e na cidade (SCHNELL, 2014). Por exemplo, o entorno do Parque Metropolitano La Sabana se compõe de bairros prestigiosos desde que a família Rohrmoser ocupava os terrenos para fazendas cafeeiras. É uma zona que, devido à proximidade com o casco urbano, o financiamento público permitiu o desenvolvimento de todas as condições gerais de produção, tanto dos meios de consumo como dos meios de circulação. Atualmente, essa área tem o equipamento urbano necessário para o desenvolvimento de empreendimentos residenciais verticais voltados para os altos segmentos sociais (SCHNELL, 2014, ACOSTA, 2016) (Figura 3).

A política urbana vigente facilita a ocupação do solo nesses bairros de alto prestígio aproveitando as mudanças introduzidas desde que a Ley Reguladora de la Propiedad en Condominio ${ }^{3}$, (e que derrogou a previa Ley de Propiedad Horizontal $N^{\circ} 3670^{4}$ de 22 de marzo de 1966), possibilitou a administração de condomínios (SCHNELL, 2014).

\footnotetext{
${ }^{3}$ Ley Reguladora de la Propiedad en Condominio. Decreto Ejecutivo $N^{\circ} 7933$, del 28 de octubre de 1999.

${ }^{4}$ Ley de Propiedad Horizontal $N^{\circ} 3670$ del 22 de marzo de 1966. Derrogada em sua totalidade pelo artigo 41 da Ley Reguladora de la Propiedad en Condominio $N^{\circ} 7933$ del 28 de octubre de 1999. 


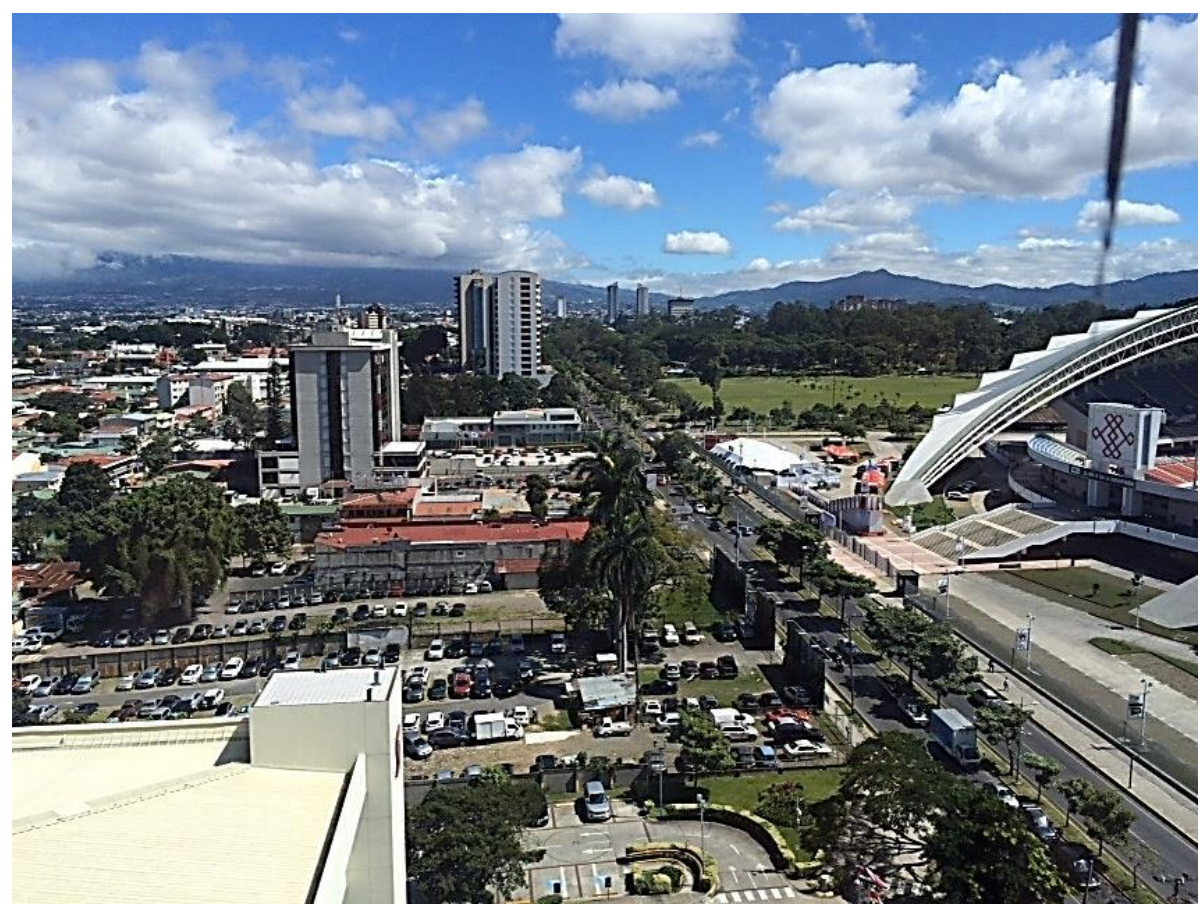

Figura 3: Vista aérea dos arredores do Parque Metropolitano La Sabana e o Estadio Nacional. Fonte: Acervo do autor, março 2016.

No território atualmente conhecido como Costa Rica, o espaço sempre foi submetido a algum tipo de planificação para atender as necessidades políticas e econômicas de algum grupo associado ao poder. No período colonial as Leyes de las Indias era o documento que regulava as normas para a fundação e organização dos povoados segundo as ordens da Coroa espanhola (SCHNELL, 2014). Atualmente, o Estado costarriquenho intervém na organização do espaço por meio do quadro legal da "planificação urbana" 5 . No entanto a intervenção estatal não pode ser reduzida a esse instrumento e nada mais. Tampouco se pode negar o efeito ideológico e jurídico sobre os agentes sociais que contêm esses documentos de urbanismo e regulamento de ocupação do solo, que se reagrupam como "planificação urbana". Por exemplo, através da aprovação de legislação, o Estado facilita e promove os investimentos ${ }^{6}$.

O Estado também pode agir indiretamente. Quanto ao financiamento, mesmo que existam projetos que não tenham relação direta com o Estado, este pode participar indiretamente do processo subsidiando tanto os produtos para a construção como o consumidor, mediante os créditos para construção e compra de moradia (SCHNELL, 2014). O Estado abre possibilidades para o desenvolvimento da verticalização mediante a tomada de decisões políticas envolvidas na permissão para a construção do espaço vertical. Por conseguinte, no contexto da legislação, o Estado participa do:

“[...] movimento da realidade social, em que certos processos são gerados por agentes que, independente das articulações que estabelecem entre si diretamente, no processo de acumulação, carecem de uma 'legitimação social', possibilitada pelo Estado" (SOUZA, 1994, p. 219).

Entre outros papéis do Estado, destacam-se atualizar o marco jurídico de produção e uso do espaço, taxar a propriedade fundiária, produzir as condições de produção para outros agentes sociais (estradas, sistemas de energia, água e esgotamento sanitário, entre outros), controlar o mercado fundiário, ser promotor imobiliário e industrial (CORRÊA, 2011).

\footnotetext{
${ }^{5}$ Diversos questionamentos têm surgido entorno à efetividade e atualização deste quadro legal. Ver ARIAS, 2001; JANQUILEVICH, 1988; MORA, 2001.

${ }^{6}$ Por exemplo, na primeira quinzena de dezembro de 2013, se aprovou uma reforma à Ley del Sistema Financiero Nacional para la Vivienda a qual facilita uma maior participação de entidades não financeiras (como as mutuales), para outorgar créditos destinados aos segmentos médios. 
Para Lojkine (1997, p. 202) esses diversos papéis podem ser classificados da seguinte maneira: Uma dimensão "planificadora"; uma dimensão "operacional" que é o conjunto de práticas reais pelas quais o Estado central e os aparelhos estatais locais intervêm financeira e juridicamente na organização do espaço; uma dimensão propriamente urbanística que condensa, materializa e mede, por isso mesmo, os efeitos sociais -no espaço- do par planificação urbana/operações de urbanismo.

Lojkine (1997) enfatiza que uma política urbana coerente não é uma vontade, ou uma decisão, nem um projeto. A coerência reside na relação plano/operações de urbanismo sobre o conjunto da organização social do espaço. Este está sendo o desafio da prefeitura de San José para manter essa coerência em um contexto onde culturalmente a população ainda não está acostumada a identificar e enfrentar os desafios da moradia residencial vertical. Como se mencionou previamente, no caso costarriquenho, a intervenção estatal tem tido dificuldades no que se refere à coordenação institucional para a planificação urbana, o que se concretiza na atual luta entre decisões e projetos do capital privado e a necessidade de conseguir a coerência proposta por Lojkine (1997) (SCHNELL, 2014).

Introduz-se uma hipótese na qual é possível que os agentes do poder do Estado não tenham nenhuma consciência da política urbana real que eles ajudam a pôr em funcionamento (LOJKINE, 1997). No caso costarriquenho, novas políticas urbanas estão em vias de aprovação com o intuito de fazer frente à urgente necessidade de planificação em um cenário no qual o capital privado é fortemente atuante, característica do forte urbanismo liberal atual (SCHNELL, 2014). Segundo Lojkine (1997), existe uma inconsciência e ausência de domínio dos processos de urbanização nessa sociedade histórica e geograficamente determinada e que, no caso costarriquenho, estava acostumada a um padrão de desenvolvimento horizontal até inícios do século XXI, quando deu inicio a verticalização residencial como símbolo de luxo ${ }^{7}$.

Já que a relação do Estado com os outros agentes é complexa, podemos propor outro ponto de vista para analisar o papel do Estado e desvendar outros detalhes expostos segundo a visão de Jaramillo (2009) (SCHNELL, 2014). O Estado intervém pela via fiscal, ou seja, o Estado cobra impostos e isso afeta os preços do solo urbano condicionando a prática dos agentes. Desde o período colonial, os camponeses estavam acostumados a ter uma economia de subsistência paralela a uma economia "aberta" relacionada ao pagamento de tributos para os espanhóis. Atualmente o Estado é o receptor desse tipo de tributos. Também a regulamentação urbana, como segundo ponto, incide sobre os usos e densidades das construções. Como se mencionou, desde que existiam as Leyes de las Indias como regulamentação urbana, se exerce controle sobre a população e a ocupação do solo. Na atualidade, o Estado procura uma coêrencia, equidade e eficiência, entre outros objetivos, que o mercado imobiliário não é capaz de facilitar e assim tenta evitar efeitos indesejáveis como, por exemplo, a hiperdensificação, a segregação socioespacial, a congestão e proliferação de terrenos com fins especulativos, entre outros. Estas tentativas fazem parte de um tema complexo no quadro da urbanização neoliberal e que sai dos alcances deste artigo.

Continuando com a análise do papel do Estado, também cabe destacar que as leis não são a única forma de exitosamente fomentar um novo uso do solo em determinada área, razão pela qual é necessária a participaçao do mercado imobiliário para que atraia ou rejeite determinados usos dependendo de seus investimentos. Por outro lado, a eliminação de um determinado uso do solo ou sua inclusão pode fomentar aumentos e quedas nos preços do solo urbano (SCHNELL, 2014).

Uma terceira via para analisar o papel do Estado inclui a ação deste como provedor de infraestrutura. Os investimentos em meios de transporte, espaços públicos, serviços básicos, entre outras variáveis, estão associados aos aumentos de preços dos terrenos. No caso de San José como cidade capital, é uma área com abundantes meios de consumo coletivo, o que valoriza o preço da terra (SCHNELL, 2014).

Uma quarta análise do Estado é desde o ponto de vista como agente imobiliário, tanto como proprietário como produtor do espaço construído. Uma quinta via exposta por Jaramillo (2009) analisa diversos fatores, como, por exemplo, a especulação ${ }^{8}$, circunstâncias não econômicas que atrasam as

\footnotetext{
${ }^{7}$ Também, a partir da segunda década do século XXI têm surgido projetos para retomar a verticalização associada a moradias de bem social. Cabe esclarecer que desde a década de 1950 a verticalização residencial iniciou como solução habitacional para os segmentos mais baixos. Em 1954 foi criado o Instituto Nacional de Vivienda y Urbanismo, cujos primeiros projetos foram semelhantes ao programa Minha Casa, Minha Vida, no Brasil. Estes projetos foram conhecidos como multifamiliares e, por conseguinte a verticalização residencial foi estigmatizada e associada aos segmentos sociais de menor poder aquisitivo. Atualmente, reformas na Ley Reguladora de la Propiedad en Condominio vão permitir diminuir o custo de construção de torres para moradias de bem social.

${ }^{8}$ A especulação, que pode ser passiva, segundo Jaramillo (2009), ocorre quando o especulador não é o causante dos aumentos nos preços do solo urbano. Essa figura somente observa os planos e execuções estatais com o propósito de que incidam de maneira positiva em suas propriedades. Também existe a especulação indutiva em que grandes agentes, como construtoras, manipulam a legislação em seu favor. Dessa maneira lhes permite dirigir e reorientar os preços do solo. Compram-se terrenos com preços que correspondem a usos determinados e posteriormente com seu poder de investimento, constroem com especificações que elevam os preços e o lucro (JARAMILLO, 2009).
} 
transações, inclusive casos de proprietários que se recusam a separar-se de sua terra por motivos culturais, econômicos, políticos ou de prestígio social. Um exemplo é o caso de camponeses que recusam vender suas terras já que isto implicaria uma mudança radical em seu trabalho quotidiano. Também estão as familias tradicionais que se recusam a vender suas casas de herança familiar, o que dificulta a proliferação de novos empreendimentos (SCHNELL, 2014). A seguir se apresentam alguns dos conflitos que caracterizam as relações entre os agentes participantes no mercado imobiliário.

\section{Conflitos entre os agentes}

Através de uma perspectiva de relações entre os diferentes agentes, diversos conflitos podem ser identificados dependendo de seus interesses e agendas (SCHNELL, 2014). Podemos destacar os seguintes: Agentes urbanos dominantes (representados pelo Estado) versus a população; Agentes capitalistas privados versus Estado e Agentes capitalistas versus outros agentes capitalistas.

Esses conflitos se observam, por exemplo, nos empreendimentos localizados nas áreas circundantes ao Parque Metropolitano La Sabana. Diversos agentes capitalistas (empresas incorporadoras) disputam as melhores localizações nesses bairros de segmentos médio-altos. Essa disputa também ocorre entre o Estado e a população. Embora muitos moradores prefiram dar lugar aos edifícios para poder valorizar seus imóveis, se aprecia na média uma tendência a criticar esse fenômeno. Por exemplo, em dezembro de 2012, o exdeputado José Luis Fishman expressou seu desconforto com respeito às novas torres residenciais que estavam surgindo no seu bairro, especialmente aquelas que afetavam a privacidade de sua casa. Este é um de muitos casos em que a população mostra incerteza, preocupação e até desconforto a respeito dos novos empreendimentos (Figura 4). "La Municipalidad de San José ha sido incapaz de realizar una regulación adecuada respecto a este tema; hemos planteado quejas y no hemos tenido respuesta", afirmou Fishman (BARRANTES, 2013). Finalmente, o ex-deputado, bem como outros moradores, decidiu mudar-se longe das torres que estão "pipocando" nestes bairros (SCHNELL, 2014).

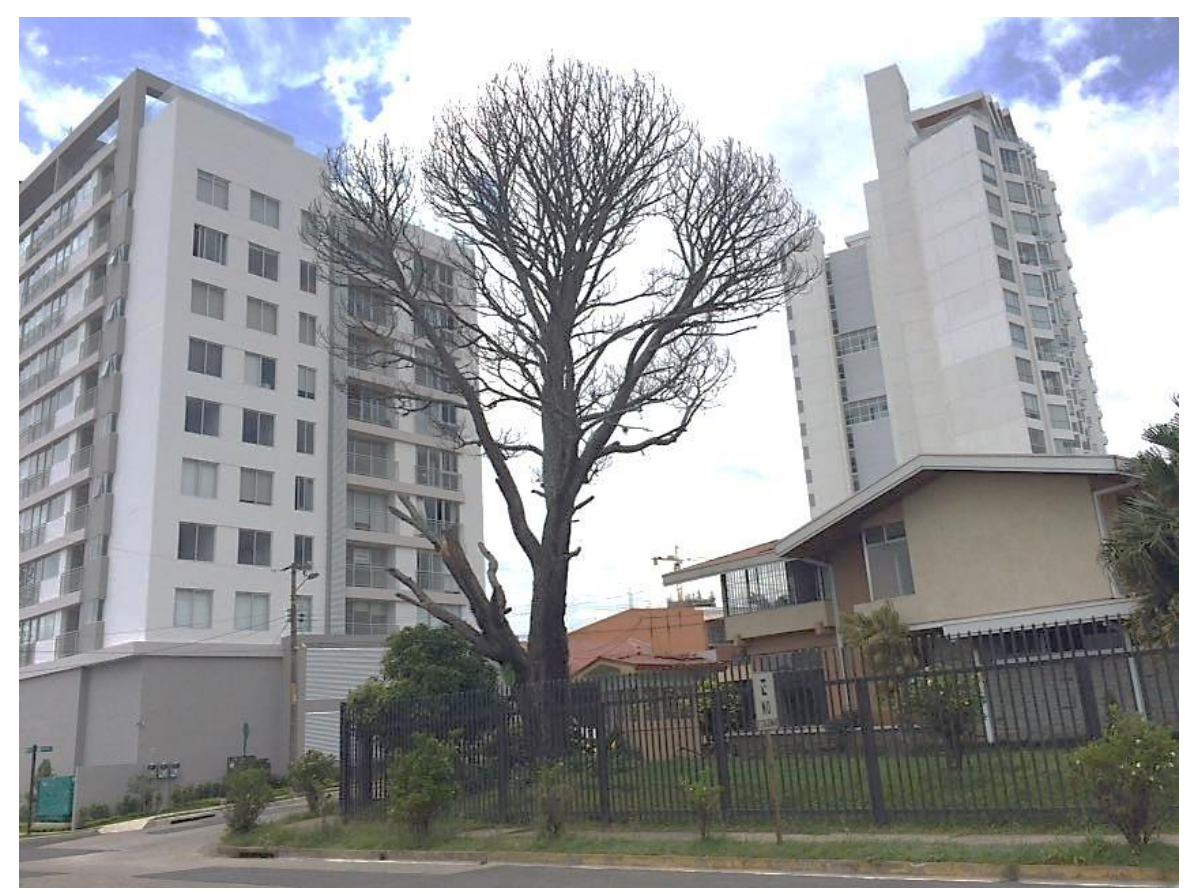

Figura 4: Projetos residenciais verticais proliferam em bairros que tradicionalmente fizeram parte de bairros de alto padrão com espaçosas casas horizontais com amplos jardins. Fonte: Acervo do autor, Julho 2016. 
Outra preocupação entre os moradores e vizinhos tem sido o aumento do fluxo veicular devido ao adensamento populacional. María Elena Guth (BARRANTES, 2013), vizinha do Parque Metropolitano La Sabana, expressou para o jornal: "Reconozco que este tipo de obras aportan plusvalía al terreno; sin embargo, me preocupa que se pierda la tranquilidad por el flujo vehicular." No entanto, no contexto das disputas entre a população e os capitalistas, o Estado promove esse tipo de solução habitacional com o objetivo de maximizar o uso do solo. Nesse caso, o Estado aparece como legitimador dos interesses privados (SCHNELL, 2014).

Por outro lado, vizinhos, como Jacob Dalfin, estão a favor do desenvolvimento vertical e inclusive comparam esse cenário ao Central Park (Nova Iorque), que está rodeado de edifícios verticais (BARRANTES, 2013). Os que estão a favor do desenvolvimento vertical, percebem que estes projetos beneficiam a localidade. Por exemplo, o arquiteto José Luis Salinas expõe que: "Una vez que un edificio de estos se levanta en la ciudad, sus alrededores muestran cambios significativos para el bien de la comunidad."

Nesse contexto, seguindo a linha exposta por Souza (1994), podemos observar que a participação e relacionamento entre esses diferentes agentes permite entender que a cidade cresce porque existe uma multiplicidade e complexidade de interesses nela envolvidos e esses interesses são lucrativos na produção do espaço urbano, tanto público como privado. Aqui o Estado atua como regulador e como capitalista contraditoriamente (SCHNELL, 2014). Silvério (2011) apresenta o conflito entre os interesses dos agentes do mercado imobiliário e os governos locais, da seguinte maneira:

Os agentes do mercado imobiliário procuram conseguir dos governos locais as condições básicas para a viabilização de seus novos produtos. Entretanto, o âmbito destas intervenções é variado e suas consequências extrapolam os limites do município, especialmente em regiões metropolitanas. Os grandes empreendimentos [...] costumam demandar uma reordenação na infraestrutura regional, orientando em muitos sentidos a valorização das terras urbanas e promovendo outras formas e padrões de urbanização (SILVÉRIO, 2011).

Dessa maneira, se observa como a expansão urbana é dirigida pelos interesses imobiliários que exercem pressão sobre as prefeituras que são as instâncias que definem parâmetros como o perímetro urbano, controlam o parcelamento, a altura dos edifícios, o uso e ocupação do solo, entre outros (SILVÉRIO, 2011).

Assim se observa que a verticalização como processo tem implicações na organização do território e na qualidade de vida urbana, e, por conseguinte, é um processo de natureza política que implica o relacionamento entre os diferentes agentes, embora seja de forma contraditória (SOUZA, 1994).

\section{CONSIDERAÇÕES FINAIS}

Atualmente, o auge imobiliário, que está caracterizando diversos pontos estratégicos da Costa Rica, como se observou no exemplo das áreas circundantes ao Parque Metropolitano La Sabana, permitiu desvendar que existe uma rede de agentes envolvidos que têm influência na dinâmica do mercado imobiliário. Esta rede de atores se torna mais complexa quando vários participantes adotam diversos papéis realizando múltiplas intervenções na produção do espaço urbano.

Analisou-se o papel do Estado desde um marco referencial teórico que não tinha sido abordado amplamente nos estudos de geografia urbana costarriquenha, para assim poder observar seu papel desde diversas perspectivas. O Estado adota um papel contraditório já que atua como regulador ou como interventor, de maneira direta ou indireta. Também intervém desde o ponto de vista legal, fiscal e como provedor de meios de consumo coletivo. Todas estas visões fazem parte da complexidade que está em jogo no recente auge de verticalização residencial tanto de luxo como para bem social (SCHNELL, 2014).

Observou-se como desde o período colonial até a atualidade, no controle sobre o uso do solo e na planificação da ocupação, têm participado diversos atores. Comprovou-se, como atualmente, no quadro da urbanização neoliberal, onde o mercado dita as direções e intenções dos investimentos, a rede de participação também se torna mais complexa. 


\section{REFERÊNCIAS}

ACOSTA, S. As recentes tendências do mercado imobiliário costarriquenho. Revista Geo UERJ, Rio de Janeiro, n. 28, p.1-25, 2016.

ARIAS, C. Nacimiento, muerte y resurrección del Plan Nacional de Desarrollo Urbano. Revista Ambientico, San José, número 99, p. 7-8, 2001.

BARRANTES, A. Vecinos alistan maletas por llegada de edificios. La Nación. San José, 9 de dezembro 2013. Disponível em: <http://www.nacion.com/nacional/comunidades/Vecinos-alistan-maletas-llegadaedificios 0 1310269075.html>. Acesso em: 22 jan. 2016.1p.

CORRÊA, R. L. Sobre agentes sociais, escala e produção do espaço: um texto para discussão. In: CARLOS, Ana Fani Alessandri; SOUZA, Marcelo Lopes de; SPOSITO, Maria Encarnação Beltrão. A produção do espaço urbano: agentes e processos, escalas e desafios. São Paulo: Contexto, 2011.19p.

JANKILEVICH, C. El problema Metropolitano de Costa Rica: alternativas de ordenamiento territorial. Revista Geoistmo, San José, II, (2), p. 23-50, 1988.

JARAMILLO, Samuel. Hacia una teoría de la renta del suelo urbano. (2ed). Bogotá: Universidad de los Andes, Facultad de Economía, CEDE, Ediciones Uniandes, 2009.12p.

LOJKINE, J. O Estado capitalista e a questão urbana. São Paulo: Martins Fontes, 1997.360p.

MARICATO, E. Globalization and urban policy on the periphery of Capitalism. 2006. Disponível em: http://www.usp.br/fau/depprojeto/labhab/biblioteca/textos/maricato_globalizationurbanpolicy.pdf. Acesso em: 6 mar. 2016.

MORA, P. Deficiencias y escollos de los planes reguladores. Revista Ambientico, número 99, p. 9-10, 2001.

PEREIRA, E. Gestão do espaço urbano: um estudo de caso das áreas central e continental da cidade de Florianópolis. 161f. Dissertação (mestrado em Administração) - Universidade Federal de Santa Catarina, Florianópolis. 1992.

SCHNELL, S. Expansão urbana em San José, Costa Rica: da formação da metrópole à verticalização. Dissertação (Mestrado em geografia) - Universidade Federal de Santa Catarina, Florianópolis, 2014. 305p.

SILVÉRIO, M.C. Mercado imobiliário e a expansão urbana pós-1990 na Região Metropolitana de Campinas. In: MEDONÇA, J de G.; COSTA, H. S. de M. (ORGS). Estado e capital imobiliário. Convergências atuais na produção do espaço urbano brasileiro. Belo Horizonte: C/Arte, 2011.350p.

SOUZA, M. A. DE. A identidade da metrópole. A verticalização em São Paulo. São Paulo: Huitec, 1994. $257 \mathrm{p}$. 